\title{
1. Introduction to Japan, the European Union and global governance: setting the scene ${ }^{1}$
}

\author{
Eiji Ogawa, Kolja Raube, Camille Van der \\ Vorst, Dimitri Vanoverbeke and Jan Wouters
}

\section{INTRODUCTION}

The present volume aims to examine, understand and assess the growing cooperation and solidarity between two mega economies, Japan and the European Union (EU or Union), in what can be described as times of contestation of the current international order. ${ }^{2}$ It is indeed remarkable that in the midst of growing global tensions Japan and the EU are deepening their cooperative relationship. The 2018 Economic Partnership Agreement (EPA) ${ }^{3}$ and Strategic Partnership Agreement (SPA) ${ }^{4}$ are the foremost expressions of Japan's and the

1 This research started with collaboration between scholars at Hitotsubashi University and KU Leuven and with support by the FWO (Research Foundation Flanders). The FWO funded the project titled 'The Relationship between the EU and Japan in times of crisis - Towards Avenues in Financial Governance Institutions,' FWO number VS.021.14N.

2 Funabashi, Y. and G. J. Ikenberry (eds), The Crisis of Liberal Internationalism: Japan and the World Order, Brookings Institution Press, 2020.

3 Agreement between the European Union and Japan for an Economic Partnership, OJ L 330, 27/12/2018, p. 3. For the EU's decision on signature, see Council Decision (EU) 2018/966 of 6 July 2018, OJ L 174, p. 1; for the EU's conclusion of the agreement, see Council Decision (EU) 2018/1907 of 20 December 2018 (OJ L 330, 27/12/2018, p. 1).

4 Strategic Partnership Agreement between the European Union and its Member States, of the one part, and Japan, of the other part, OJ L 216, 24/8/2018, p. 4; for the EU's decision on signature and provisional application, see Council Decision (EU) 2018/1197 of 26 June 2018 on the signing, on behalf of the European Union, and provisional application of the Strategic Partnership Agreement between the European Union and its Member States, of the one part, and Japan, of the other part, OJ L 216 , 24/8/2018, p. 1 . 
EU's will to cooperate ever more deeply and in a more structured way, both bilaterally and multilaterally, in the context of global governance.

Despite their long-lasting competition in the global economy (see infra), for many decades Japan and the EU have been able to 'build a house' of common understandings brick by brick, in which a level playing field and transparent rules aimed to pave the way for new ways of global engagement. Lately, the two have been working on a deeper level of cooperation that not only tries to reinforce mutual ties between the two mega economies, but that also aims to globally foster shared norms, principles and standards - not the least because both of them have seen themselves as prime examples of normative power in the Western and Eastern hemispheres for a long time. In other words, in times of 'turbulence in world order's both Japan and the EU are trying to contribute to a consolidation and deepening of their bilateral relations and to work towards a stabilisation of the multilateral order. Simultaneously, they have to take into account an increasingly unpredictable US, the aggressive rise of China, risks of stagnation and fragmentation, and an ever more prominent contestation of the existing international order by multiple actors. ${ }^{6}$ All these developments take place in a 'world of regions' that calls for area-based knowledge ${ }^{7}$ such as that provided in this volume.

\section{FROM COMPETITION TO DEEPER COOPERATION}

To be sure, the relationship between the EU and Japan was not always a harmonious one. On the contrary, it could be argued that cooperation between the two was initiated because of trade issues in the previous century that could not be solved unilaterally. The 1970s, 1980s and 1990s were turbulent times for EU-Japan relations. There was no framework for cooperation between the two actors at that time, mostly because they regarded each other more as economic competitors than as potential partners in global governance.

Although today's discourse about EU-Japan relations focuses heavily on shared values, including the belief in a market economy, during the 1970s and 1980s there was a much stronger awareness of the differences between these actors. Writings about Japan's economic miracle stressed the important role

5 Rosenau, James N., Turbulence in World Order - A Theory of Change and Continuity, Princeton University Press, 1992.

6 Kahler, Miles, 'Regional challenges to global governance', Global Policy 8(1) (2017): 97-100; Zürn, Michael, A Theory of Global Governance - Authority, Legitimacy and Contestation, Oxford University Press, 2019.

7 Katzenstein, Peter J., A World of Regions: Asia and Europe in the American Imperium, Cornell University Press, 2005. 
of government intervention to promote and guide industrial development. ${ }^{8}$ Western businesses attributed the international success of Japanese products to the fact that Japanese businesses were receiving government subsidies. ${ }^{9,10}$ Interestingly, at least on the surface, the Japanese market seemed relatively open compared to the American or European markets at the time. After criticism from the US and Europe in the 1970s, Japan had introduced ten 'market opening packages' in the 1980s, leading to lower average tariffs than those in the US and Europe. ${ }^{11}$ However, in spite of these lower tariffs, Japan received explicit complaints about its non-tariff barriers (NTBs) that were deemed prohibitively high and it was these NTBs that were the main concern of European and American exporters in the $1970 \mathrm{~s}-80 \mathrm{~s}^{12}$

As a consequence of trade tensions, individual European countries took protective measures against Japan. ${ }^{13}$ The scattered response by individual Member States led the European Commission in 1980 to adopt a communication in which it argued in favour of a re-examination of the European Economic Community's (EEC) trade policy towards Japan. In the Commission's view, the individual protective measures were undermining the common commercial policy and there was a need for an approach based on the combined strength of the Community. ${ }^{14}$ By 1985, the EEC and Japan were discussing a proposal ${ }^{15}$ to establish an EEC-Japan industrial cooperation centre which was established

\footnotetext{
8 Jéquier, N., Le Défi industriel japonais, 1st edn, Centre de recherches européennes, 1970, p. 120.

9 Flath, David, The Japanese Economy, 2nd edn, Oxford University Press, 2005, p. 179.
}

10 After US producers of semi-conductors signed a petition invoking Section 301 of the Trade Act of 1974 against the government of Japan, the US and Japan signed the Arrangement concerning Trade in Semi-Conductor Products in 1986. Subsequently, the European Economic Community brought a GATT complaint against Japan stating that this arrangement violated Art.1, Art. 6, Art. 10 and Art. 11 of the GATT. See 'Japan - Trade in Semi-Conductors: Report of the Panel Adopted on 4 May 1988', GATT Report L/6309-35S/116, 24 March, 1988.

11 Nester, William R., European Power and the Japanese Challenge, Palgrave Macmillan UK, 1993, p. 128.

12 Abe, T., "The "Japan problem": the trade conflict between the European countries and Japan in the last quarter of the 20th century', Enterprises et histoires, 80(3) (September 2015): 13-35, 193-194.

13 Ibid.

14 'The Trade Policy of the Community and Japan: A Re-Examination', Communication from the Commission to the Council, Brussels, 15 July 1980. 'COM(80) 758 final: International Trade Problems', Communication from the Commission to the Council, Brussels, 20 November 1980. See also: 'COM(81) 325 final: Commercial Relations between the Community, the United States and Japan', Communication from the Commission to the Council, Brussels, 18 June 1981.

15 'Relations with Japan 1986', European Parliament, 16 December 1986. 
the next year. ${ }^{16}$ The real turning point for Europe-Japan relations took place in 1991, when the two actors signed an ambitious joint declaration that set out the foundations for future dialogue, cooperation and consultations. ${ }^{17}$ The preamble of this declaration, also referred to as the 'Hague Declaration', highlights the regions' 'common attachment to freedom, democracy, the rule of law and human rights': values that have since been repeated throughout EU-Japan cooperation. ${ }^{18}$ Trade continued to be a sensitive issue during the 1990s. ${ }^{19}$ However, because of Japan's economic downturn after the collapse of the bubble economy in 1991, it was regarded as less of a threat during this decade. ${ }^{20}$ Another milestone was reached in 2001 when the EU and Japan concluded an Action Plan for EU-Japan Cooperation. ${ }^{21}$ The goal of this Action Plan was to shape the 'common future' of the two actors. While trade is still mentioned as one of the areas of cooperation, the focus also shifted to other areas of global governance, such as peace and security, research and development and the global fight against poverty. ${ }^{22}$ Both the Hague Declaration and

16 92/278/EEC: Council Decision of 18 May 1992 confirming the consolidation of the EC-Japan Centre for Industrial Cooperation, Pub. L. No. 31992D0278, 144 OJ L (1992).

17 Joint Declaration on Relations between the European Community and its Member States and Japan, 1991, accessed via: http://eeas.europa.eu/archives/docs/ japan/docs/joint_pol_decl_en.pdf.

18 See Vanoverbeke and Van der Vorst (Chapter 4 of this book) and Gilson, Julie, 'The Strategic Partnership Agreement between the EU and Japan: the pitfalls of path dependency?', Journal of European Integration, 38(7) (November 2016): 791-806.

19 Trade with Japan continued to be a sensitive issue for both Europe and the US: in 1990 the US Congress published a report on the challenges for US trade with Japan. However, just like in Europe, there seemed to be a growing realisation in the US that these issues could not be resolved by conflict alone. The report warned against the use of frequent threats and ultimatums as this could have negative consequences and would paint the US in a bad light to Japanese citizens. It is explained that 'Trade disputes are front page news in Japan and tend to be portrayed in the imagery of war.' See 'Japan's Economic Challenge', Study Papers Submitted to the Joint Economic Committee Congress of the United States, Washington: Joint Economic Committee, October 1990, p. 423.

20 Vanoverbeke, Dimitri, 'The Dynamics in the EU-Japan Relationship', in EUJapan Relations, 1970-2012. From Confrontation to Global Partnership, edited by Jörn Keck, Dimitri Vanoverbeke and Franz Waldenberger, Routledge, 2013, pp. 329-337. See also: Keck, Jörn, '1990-1995 - The politics of cooperation', in EU-Japan Relations, 1970-2012. From Confrontation to Global Partnership, edited by Jörn Keck, Dimitri Vanoverbeke and Franz Waldenberger, Routledge, 2013, pp. 111-130.

${ }^{21}$ An Action Plan for EU-Japan Cooperation: European Union-Japan Summit Brussels, 2001, accessed via: www.mofa.go.jp/region/europe/eu/summit/action0112 .html.

22 Ibid. 
the Action Plan can be seen as important stepping stones in the rapprochement between the EU and Japan that eventually led to the negotiations for the EPA and SPA. ${ }^{23}$ Vanoverbeke and Van der Vorst (Chapter 4) further describe the changing relationship between Japan and Europe throughout the last quarter of the previous century, and up to 2020 .

Before 2011, cooperation on trade was much lower than might be expected. Based on the respective size of the European and Japanese economies, despite their geographical distance, trade values could be much higher. ${ }^{24}$ There are other Asian countries for which trade with the EU has untapped potential, such as China. However, trade between Japan and the EU was low even when compared to other Asian countries without preferential trade agreements (PTAs). Research suggests that the reasons for this untapped potential on trade included the abundance of NTBs in the EU and in Japan and trade-diverting effects caused by other PTAs. ${ }^{25}$ It is therefore very positive that the EU-Japan EPA pays ample attention to NTBs, although it remains to be seen whether the commitments on this matter will have the intended liberalising effect. Van der Vorst (Chapter 5) delves deeper into the most burdensome NTBs and whether these have been resolved as a result of the EPA. Moreover, the EPA should correct the previous trade-diverting effects. For example, the Japanese car sector will now come on an equal footing again with South Korean car exporters, which have benefitted from a free trade agreement (FTA) with the EU since 2011.

Ever since cooperation between the EU and Japan started to pick up, their commitments on global governance have been characterised by a high level of ambition. And yet, until recently, few of these commitments had materialised. What happened in 2018 and 2019 is therefore rather remarkable. The Union and Japan were able to change the usual path and turned talking into action. Whereas cooperation was originally born from disputed trade relations, Japan and the EU are increasingly becoming more than economic partners.

The recent video-teleconferenced meeting between the leaders of the EU and Japan, which took place on 25 May 2020, including Charles Michel, President of the European Council, Dr Ursula von der Leyen, President of the European Commission, and Shinzo Abe, Prime Minister of Japan, underpinned Japan's and the EU's ambition for deeper cooperation. During the

23 Gilson, Julie, 'The Strategic Partnership Agreement between the EU and Japan: the pitfalls of path dependency?', Journal of European Integration, 38(7) (November 2016): 791-806.

24 Smeets, Dieter, 'A free trade agreement between the EU and Japan-What is to be expected?', Asia Europe Journal, 13(1) (1 March 2015): 57-73, https://doi.org/10 .1007/s10308-014-0406-6.

25 Ibid. 
one-hour long call, the leaders pledged to join forces and foster 'global solidarity, cooperation and effective multilateralism'. Furthermore, the Joint Press Release added that in view of the Covid-19 pandemic, they would spare no effort to "protect lives, and mitigate the social and economic consequences in keeping with their principles and values of democracy, human rights, the rule of law, and non-discrimination' that are at the heart of the cooperation between the two powers. ${ }^{26}$ Exemplary in nature, the Press Release underlines how the bilateral relationship between Japan and the EU is constantly being updated to the current challenges that the two strategic partners are facing. Moreover, it shows the growing importance of the partnership as a bilateral act of balancing power in a turbulent world where tensions between great powers are increasingly becoming a real threat for global stability and peace. Even more than in the past, it seems that the EU and Japan will have to take concrete measures to engage with other parts of the world on the basis of their partnership. This partnership is progressively permeating not only the EU and Japan directly, but also wider international relations through Japan's and the EU's interactions with other regional actors and international organisations.

\section{THE EU-JAPAN PARTNERSHIP AND GLOBAL GOVERNANCE}

Ever since the entry into force of the EU-Japan EPA on 1 February 2019, international trade can be said to be the area where the Union and Japan have so far made their biggest mark on global trade specifically and on global governance in general.

Indeed, as can be seen from the contributions to this volume by Vanoverbeke and Van der Vorst (Chapter 4), Van der Vorst (Chapter 5) and Willemyns and Wouters (Chapter 7), the EU-Japan EPA has set a strong example for future mega FTAs and bilateral PTAs alike. The impact of the EPA is likely to be felt far beyond the EU-Japan economic relationship. Although the magnitude of expected economic externalities is relatively low, several ex ante impact assessments find a quantifiable impact on economic welfare in the rest of the world as a result of the EU-Japan EPA. ${ }^{27}$ The Japanese Research Institute of Economy, Trade and Industry (RIETI) expects that this ambitious EPA, removing both tariffs and NTBs, will reduce economic welfare in China, South Korea and the US by an equivalent of $0.1-0.2$ per cent of gross domestic

26 EU-JP, 2020, 'Joint press release: Japan-EU Leaders' meeting.'

27 Kawasaki, Kenichi, 'Rise of the mega EPAs: a comparison of economic effects', Research Institute of Economy, Trade and Industry, 4 March 2014. 
product (GDP). ${ }^{28}$ The European Commission's impact assessment report of 2012 also expects negative spillovers in a simulation of the EU-Japan EPA: this assessment reports reductions of GDP in Canada, China and India. ${ }^{29}$ Simultaneously, there might be positive spillover effects resulting from the EU and Japan's liberalisation of NTBs that could equally improve market access for third countries, as explained in the study by RIETI. ${ }^{30}$ The same Commission report from 2012 finds such positive effects on countries such as the US, Brazil and Russia, whose GDP increases slightly in the economic simulation. ${ }^{31}$ The Commission's impact assessment of 2018 goes even further and argues that third countries will benefit from increased demand from the EU and Japan as aggregate income goes up in the two partners. ${ }^{32}$ Although the various analyses report different economic effects, it is undeniable that there will be a ripple effect of the EU-Japan EPA across the world economy.

The cooperation between Japan and the EU does not stop at international trade, however. The EPA is accompanied by the SPA, which contains commitments to cooperate on a wide range of political topics and and a large part of this SPA has been provisionally applied since 1 February 2019. ${ }^{33}$ These agreements transform the bilateral relationship between the EU and Japan, but, as indicated by Raube, Andrione-Moylan and Wouters in their contribution (Chapter 2), they also have an impact beyond the bilateral level. Both parties have expressed their commitment to help shape global rule-making in an open

28 Ibid.

29 European Commission, 'Commission Staff Working Document: Impact Assessment Report on EU-Japan Trade Relations', Brussels, 18 July 2012, https://eur -lex.europa.eu/legal-content/EN/TXT/PDF/?uri=CELEX:52012SC0209\&from=en.

30 Kawasaki, Kenichi, 'Rise of the mega EPAs: a comparison of economic effects', Research Institute of Economy, Trade and Industry, 4 March 2014.

31 European Commission, 'Commission Staff Working Document: Impact Assessment Report on EU-Japan Trade Relations', Brussels, 18 July 2012, https:// eur-lex.europa.eu/legal-content/EN/TXT/PDF/?uri=CELEX:52012SC0209\&from=en. The 2012 report still assumes that the WTO Doha Round would be successful and consequently includes multilateral tariff liberalisations in the baseline scenario. This could overestimate positive results for the countries involved.

32 European Commission, 'The Economic Impact of the EU-Japan Economic Partnership Agreement (EPA) - An Analysis Prepared by the European Commission's Directorate-General for Trade', Brussels, June 2018.

33 EUR-Lex, 'Document 52018JC0010 - JOIN(2018) 10 final 2018/0121(NLE)', Brussels, 27/4/2018. The Articles that were provisionally applied are the following: Articles 1, 2, 3, 4, 5(1), 11, 12, 13, 14, 15 (with the exception of paragraph 2(b)), 16, $17,18,20,21,22,23,24,25,26,27,28,29,30,31,37,38(1), 39,40,41,42$ (with the exception of paragraph 2(c)), 43, 44, 45, 46, 47, 48(3), 49, 50, 51. These Articles concern areas of the SPA aimed at promoting peace and security, policies on transport, tourism and the environment and the establishment of the joint committee. 
and transparent way. Therefore several developments and questions need to be monitored in future EU-Japan cooperation: how will their cooperation evolve when these important agreements are implemented? How robust will the partnership be so that new challenges can be addressed effectively in due time? Will the EU-Japan partnership have an effective impact on global governance beyond the two economies?

Admittedly, the EPA and SPA are not Japan's and the EU's first attempt at shaping global governance together. Over the decades, they have often found themselves defending the same interests and values, whether at the International Monetary Fund (IMF), the World Trade Organization (WTO) or the United Nations (UN), on topics such as international trade, agriculture, finance or security. Their ongoing commitment to democracy, the rule of law and human rights has been at the very core of the discourse surrounding EU-Japan cooperation. This has trickled down into various specific agreements (e.g. the agreement on EU-Japan Cooperation in Criminal Matters ${ }^{34}$ or the Science and Technology Cooperation Agreement ${ }^{35}$ ). This can be seen in almost all Joint Press Statements accompanying progress on the negotiations of the EPA and the SPA, featuring statements such as 'We remain united by our common values of democracy, human rights and the rule of law, and by our determination to promote together a free, open and fair global economy that benefits everyone ${ }^{36}$ and again, more recently in the context of the pandemic, the EU and Japan reaffirmed their joint commitment to shared values as follows: 'The leaders confirmed that both Japan and the EU are sparing no effort to stop the COVID-19 pandemic, protect lives, and mitigate the social and economic consequences, in keeping with their principles and values of democracy, human rights, the rule of law, and non-discrimination. ${ }^{37}$ Whether it is in matters of trade, political, legal or societal challenges, the value discourse is prominent and leads the way the partnership is shaped. How this discourse has an impact on the content of the partnership and even more importantly on the practice that will ensue will have to be carefully observed and analysed by researchers and practitioners alike.

The negotiation, signature, ratification and application of the EPA and SPA were only the first steps towards deepening the relationship between Japan and

34 EU-JP, Agreement between the European Union and Japan on mutual legal assistance in criminal matters, Official Journal L 039, 12/02/2010 P. 0020-0035 (2009).

35 EU-JP, Agreement between the European Community and the Government of Japan on cooperation in science and technology, Official Journal L 90/2, 06/04/2011 P. 002-007 (2009).

36 EU-JP, 2018, 'EU-Japan Summit Joint Statement'.

37 EU-JP, 2020, 'Joint press release: Japan-EU Leaders' meeting'. 
the EU. It did not take long for Japan and the EU to reaffirm their commitment to shaping global rule-making after completing the EPA and the SPA. These agreements are a stepping stone for more and deeper collaboration, as can be seen in the Partnership on Sustainable Connectivity and Quality Infrastructure between the European Union and Japan which was signed on 27 September 2019. This so-called 'Connectivity Partnership' ${ }^{38}$ sets out to improve connectivity between Europe and Asia through cooperation on infrastructure projects by the EU and Japan. ${ }^{39}$ There are areas of cooperation in the Connectivity Partnership that were not yet explicitly addressed in the EPA or SPA, such as the development of physical and financial infrastructure. Simultaneously, the Connectivity Partnership repeats the importance of past joint commitments such as rules-based international trade and investment. 'Sustainability' is mentioned in the opening sentences as the shared value that the Partnership is based on. Concretely, Japan and the EU intend to pay due attention to the fiscal capacity and debt sustainability of partner countries in infrastructure projects, but also to the involvement of the people of the partner countries in those projects in an open and transparent way. These characteristics distinguish the Partnership from the kind of connectivity in the Chinese Belt and Road Initiative (BRI) and it seems that Japan and the EU want to propose an alternative method of connectivity to the Chinese one.

One of the main objectives of the Connectivity Partnership is to 'promote free, open, rules-based, fair, non-discriminatory and predictable regional and international trade and investment'. ${ }^{40}$ This echoes the Joint Statement by the EU and Japan at the time that the EPA was signed, where it was said that the EPA 'will be the model of high standard, free, open and fair trade and investment rules in the 21 st century' ${ }^{41}$ These principles might well characterise the trade relationship between the Union and Japan. However, it remains a question for the future whether the same standards will be upheld in their bilateral relations with other trading partners. Additionally, there is no way to predict whether future agreements will take the EPA and SPA as a model. All that can be said is that those agreements are ambitious, and that it would likely benefit

38 Esteban, M. and U. Armanini, 'The EU-Japan Connectivity Partnership: a sustainable initiative awaiting materialization', Real Instituto Elcano (4/2/2020).

39 In 2018 the European Commission had already published a strategy for EuropeAsia connectivity. The 2018 strategy explicitly mentions Japan in the context of bilateral cooperation and the 2019 Connectivity Partnership can be interpreted as part of the implementation of this strategy: European Commission and High Representative of the Union for Foreign Affairs and Security Policy. Connecting Europe and Asia - Building blocks for an EU Strategy, 19/09/2018, JOIN(2018) 31 final.

40 EU-JP, The Partnership on Sustainable Connectivity and Quality Infrastructure between the European Union and Japan, UNIQUE ID: 190927_2, Brussels, 27/09/2019.

41 EU-JP, 2018, 'EU-Japan Summit Joint Statement'. 
the ever more eroding rules-based multilateral order if they could become the stepping stone for engagement with other nations and regions so that issues of insufficient financial sustainability, insufficient consultation with the local population and insufficient involvement of local economies can be overcome. ${ }^{42}$

All of the recent agreements - the EPA, SPA and Connectivity Partnership - explicitly mention the commitment of the EU and Japan to the Paris Agreement. ${ }^{43}$ The EU-Japan EPA was in fact the first Preferential Trade Agreement ever to include such a reference. The EPA additionally includes a reference to the United Nations Framework Convention on Climate Change (UNFCCC) ${ }^{44}$ All these and other commitments to sustainable trade are included in the EPA's chapter on 'Trade and Sustainable Development', although there is little reference to sustainable development in any other part of the agreement. Once more, it is the implementation phase of the EPA which will reveal whether sustainable development will permeate all layers of EU-Japan trade or whether this will only be a superficial area of cooperation.

Some European and Japanese governmental organisations increased transnational cooperation in line with the commitments of these three agreements. In October 2018, the European Investment Bank (EIB) signed a Memorandum of Understanding (MoU) with both the Japanese Bank for International Cooperation and Nippon Export and Investment Insurance..$^{45}$ One year later, at the time of signing the Connectivity Partnership, the EIB signed an MoU with the Japanese International Cooperation Agency. ${ }^{46}$ The EIB has furthermore cooperated with Japan Post Insurance in the past on the issuance of Climate Awareness Bonds. ${ }^{47}$

Another area where Japan and the EU have made great strides is on global data management and the promoting of e-commerce. Both Japan and the

42 Esteban M. and U. Armanini, 'The EU-Japan Connectivity Partnership: a sustainable initiative awaiting materialization', Real Instituto Elcano (4/2/2020).

43 EU-Japan EPA (Art. 16.4(4)), EU-Japan SPA Art. 24, EU-Japan Partnership on Sustainable Connectivity and Quality Infrastructure (Art. 3).

44 EU-Japan EPA (Art. 16.4(4)).

45 European Investment Bank, 'EIB new cooperation with the Japan Bank for International Cooperation (JBIC) and with the Nippon Export and Investment Insurance (NEXI)', 23 October 2018, accessed via: www.eib.org/en/press/all/2018-264-eib-new -cooperation-with-the-japan-bank-for-international-cooperation-jbic-and-with-the -nippon-export-and-investment-insurance-nexi.

46 European Investment Bank, 'EIB expands its partnership with Japan's JICA', 27 September 2019, accessed via: www.eib.org/en/press/news/eib-expands-partnership -with-japan.

47 European Investment Bank, 'First PLN CAB highlights Japan Post Group's commitment to climate policy', 14 May 2019, accessed via: www.eib.org/en/investor _relations/press/2019/fi-2019-09-eib-2029-pln-cab.htm. 
Union have made efforts to regulate data management through respectively, the Law concerning the Protection of Personal Information ${ }^{48}$ and the General Data Protection Regulation (GDPR). ${ }^{49}$ Consequently, both actors have high standards regarding the protection of personal data. It comes as no surprise that at the beginning of 2019, the European Commission signed an adequacy decision on Japan allowing for the free flow of data between the two regions. ${ }^{50}$ This created the largest zone worldwide for the free and safe flow of data. Combined with the commitments to e-commerce included in the EU-Japan EPA, these measures are expected to boost digital trade between these economies.

\section{WHAT CAN BE EXPECTED FROM EU-JAPAN COOPERATION?}

All the aforementioned venues for cooperation are a testimony to the EU's and Japan's desire to foster their bilateral relations and to shape global rule-making and governance. However, by 2019, it became clear that there are countries and regions that do not want to continue to shape global governance according to the established rules. In fact, Japan and the EU are facing a crucial time in their relationship. The new stage of the partnership between the EU and Japan arises at a crucial time for the liberal international order.

First and foremost, 2019 will be especially remembered for its trade conflict between the US and China. Ever since the eruption of this dispute in 2018, the trade conflict brings back memories of Japan's trade disputes with the US and Europe during the $1970 \mathrm{~s}$ and $1980 \mathrm{~s} .{ }^{51}$ For example, there are similarities in the US's use of its Section 301, a section of the Trade Act intended to counter unfair barriers in foreign markets. This same section was invoked in the trade

48 「個人情報の保護に関する法律」The Law concerning the Protection of Private Information was enacted in 2017. Additionally there is the Japanese Personal Information Protection Commission 「個人情報保護委員会.

49 European Union, Regulation (EU) 2016/679 of the European Parliament and of the Council of 27 April 2016 on the protection of natural persons with regard to the processing of personal data and on the free movement of such data, and repealing Directive 95/46/EC (General Data Protection Regulation), Official Journal L 119/1, 04/05/2016 P. 001-088.

50 European Commission, Commission Implementing Decision (EU) 2019/419 of 23 January 2019 pursuant to Regulation (EU) 2016/679 of the European Parliament and of the Council on the adequate protection of personal data by Japan under the Act on the Protection of Personal Information, Official Journal L 76, 19/03/2019 P. 001-058.

51 It was not only the US that was engaged in a trade conflict with Japan in the previous century; trade relations with Europe were equally strained. European countries took varying measures to slow down Japanese imports while Japan applied more voluntary export restraints (VERs) to its exports to Europe. 
conflict with Japan, and the US's investigations into unfair trade barriers ultimately led to Japan's voluntary export restraints (VERs) in $1981 . .^{52}$ The accusations by the US that China is a currency manipulator equally bring back memories of the trade dispute between the US and Japan during the 1980s. Similar concerns over exchange rates at the time led to the 1985 Plaza Accord which temporarily strengthened the value of the Japanese yen against the US dollar. ${ }^{53}$ This, however, did not bring about the expected increase in American exports to Japan. Similarly, the trade strategy of the US vis-à-vis China since 2018 is not delivering the desired results for the US either.

Secondly, not only has China become more active in the WTO, it is also reshaping global governance in different ways. One example is China's highly ambitious BRI. Through the BRI China does not merely contribute to shaping trade and investment. In fact, it is offering an alternative model of governance, one that is of less or different normativity than the model pursued by the EU, carrying less conditionality. As indicated above, the EU-Japan Connectivity Partnership is a reaction to the BRI. Another recent initiative that was taken by China and that will certainly impact on global governance was the establishment of the Asian Infrastructure Investment Bank (AIIB) in 2016. Although many EU Member States have become members of the AIIB, both Japan and the US have so far not signed up to the initiative..$^{54,55}$

Thirdly, it is unclear how the role of the US in global governance will develop in the future. Specifically on the topic of trade, Japan and the EU seem to each adopt a different approach to cooperation with the US. Although Japan is committed to free, fair and rules-based trade, it signed a trade agreement with the US in 2019 that is not compatible with the rules of the WTO. ${ }^{56}$ Following Article 24.8(b) of the General Agreement on Tariffs and Trade

52 Abe, Takeshi, "The "Japan Problem": the trade conflict between the European countries and Japan in the last quarter of the 20th century', Enterprises et histoires, 80(3) (September 2015): 13-35, 193-194.

53 Green, R. A., D. H. Papell and R. Prodan, 'Why was the Plaza Accord unique?', in International Monetary Cooperation - Lessons from the Plaza Accord After Thirty Years, edited by C. F. Bergsten and R. A. Green, Peterson Institute for International Economics, 2016.

54 Dollar, David, 'The AIIB and the "One Belt, One Road"', The Brookings Institution (blog), 21 June 2015, www.brookings.edu/opinions/the-aiib-and-the-one -belt-one-road/.

55 'Members of the Bank - AIIB', Asian Infrastructure Investment Bank, accessed via: www.aiib.org/en/about-aiib/governance/members-of-bank/index.html, 8 July 2020.

56 Linscott, Mark, 'The US-Japan Trade Deal Could Undermine the WTO', Atlantic Council (blog), 22 October 2019, www.atlanticcouncil.org/blogs/new-atlanticist/the-us -japan-trade-deal-could-undermine-the-wto/. 
(GATT) a free trade area can be established only if duties are eliminated on substantially all the trade between the signatories, which is not the case for the Japan-US agreement. ${ }^{57}$ Moreover, at the end of 2019 the Appellate Body of the WTO stopped functioning as the result of the US blocking the (re-) appointment of Appellate Body members. In reaction to this situation, the EU and other WTO Members such as China, Brazil and Canada brought forth the Multiparty Interim Appeal Arbitration Arrangement. ${ }^{58}$ Japan has not endorsed this arrangement, likely out of fear of alienating the US by siding with the EU on this matter. Already in December 2018 the EU, together with countries such as China, Canada and India, delivered a communication to the WTO where they expressed their concerns about the future of the Dispute Settlement Body and proposed amendments to try and resolve the issue. In this instance as well, Japan chose not to participate. ${ }^{59}$

Next to these looming crises and instabilities, both Japan and the EU struggle themselves with regional contestation and instabilities that likely have an impact on their trading power, political credibility and ability to align third parties behind their global objectives. For example, Japan's dispute with South Korea over unresolved wartime crimes committed by Japan led the two countries into a trade conflict. ${ }^{60}$ The EU itself struggles to find a deal with the United Kingdom on a trade agreement post-Brexit, while economic sanctions towards Russia remain in place. Lastly, both Japan and the Union are likely to drift into an economic recession post-Covid-19 of unprecedented levels and with large political and societal impacts that overall may at least question Japan's and the EU's global ambitions in the years to come. It is exactly against this rather peculiar background that the various existing agreements between Japan and the EU (e.g. EPA, SPA, the EU-Japan Partnership on Connectivity) have to prove that the partnership can live up to its far-reaching expectations especially in times of crises, such as the contestation of the liberal international

57 GATT 1994, General Agreement on Tariffs and Trade 1994, 15 April 1994, Marrakesh Agreement Establishing the World Trade Organization, Annex 1A, 1867 U.N.T.S. 187, 33 I.L.M. 1153 (1994).

58 Council of the European Union, 'Multi-Party Interim Appeal Arbitration Arrangement Pursuant to Article 25 of the DSU', 7112/20 LIMITE WTO 61, 02/04/2020, www.consilium.europa.eu/media/43334/st07112-en20.pdf.

59 World Trade Organization, 'Communication from the European Union, China, Canada, India, Norway, New Zealand, Switzerland, Australia, Republic of Korea, Iceland, Singapore and Mexico to the General Council', WT/GC/W/752, 26/11/2018.

60 The EU remained silent about the conflict that erupted between Japan and South Korea during the summer of 2019. Instead China and the United States took up a more active role of mediator. Tiezzi, Shannon, 'China urges dialogue during trilateral meet with Japan, South Korea', The Diplomat, 23 August 2019, https://thediplomat.com/ 2019/08/china-urges-dialogue-during-trilateral-meet-with-japan-south-korea/. 
order, the Covid-19 related looming global economic recession and the rise of regional instabilities.

Implementation of the various agreements will be the next test to assess whether Japan and the EU remain geographically distant friends or meet each other in an effective partnership with mutual gains, both bilaterally, but also multilaterally and globally. Only when trust in the bilateral partnership between Japan and the EU grows from bottom-up will the partnership become robust and have a positive impact on the international multilateral order. At the same time, the next decade of implementing the partnership will be essential for the legitimacy of the partnership's leadership on the global scene. The collaboration between Japan and the EU in the two decades after 2000 was often characterised by 'untapped potential' and it is too early to assess whether the partnership can move beyond this characterisation. Yet, the speed at which the institutions and context of the EU-Japan partnership have been developing in recent years is indeed impressive and hints at a window of opportunity for the partnership to become an example for new and positive forms of connectivity around the world. Needless to say, trade remains important as can be seen from the many contributions to this volume. However, what also transpires in various chapters, such as the ones by Oshiba (Chapter 3), Reiterer (Chapter 9), and by Raube, Andrione-Moylan and Wouters (Chapter 2), is the need to engage on non-trade related issues with other nations (e.g. the US and China) and with other regions (e.g. South East Asia and Africa). Needless to say, the various experiences and histories will impact the way that Japan and the EU proceed with the implementation of the partnership.

\section{STRUCTURE OF THIS VOLUME}

In this volume, scholars from Europe and Japan address important issues of the EU-Japan partnership to assess the future potential of the partnership in the context of global governance. The contributions are balanced between focus on Japan and focus on the EU and between analyses of the past and present and always with an eye to the difficulties and possibilities for the future of the partnership in a changing international order.

In the second chapter, Kolja Raube, Alex Andrione-Moyne and Jan Wouters provide a framework for the topical discussions that will follow in this edited volume by framing EU-Japan cooperation within the EU's multilateral approach to global governance. The chapter clearly illustrates the EU's strong and institutionalised commitment to multilateralism. However, international contestation is identified as one of the key challenges that are limiting the EU's dedication to multilateralism. Consequently, this chapter finds differences in the EU's normative commitment to multilateralism and its international practices that are highly impacted by contestation. Although there are constraints to 
the EU's 'effective multilateralism', the authors find that the EU has navigated international contestation by complementing multilateralism with bilateral cooperation such as with Japan.

In the third chapter, Ryo Oshiba addresses one of the most important challenges for Japan in global governance today: the role Japan should assume now and in the heavily changing landscape of the future. The chapter investigates mainly the area of financial governance and looks at Japan's participation in the World Bank and the G7 summits. The chapter takes a historical perspective. Lessons are drawn from Japan's past experiences with the Asian financial crisis, the establishment of the Asian Development Bank and the Asian Infrastructure Investment Bank. From these and other experiences, conclusions are formulated about the role which Japan can assume in global governance and where there is room for cooperation with the EU.

Chapter 4 (Dimitri Vanoverbeke and Camille Van der Vorst) takes a historical look at the cooperation between Japan and the EU on economic governance. The chapter mainly asks which elements form the main motivation for cooperation between the regions. It illustrates how the relationship on economic governance between the two actors has changed drastically over the past few decades. The EU evolved from seeing Japan as a competitor in international trade during the previous century, to seeing Japan as one of its strategic partners in the current age. The chapter pays attention to the real, practical reasons that have driven this rapprochement by analysing different sources of discourse, such as Japanese newspapers, joint press statements and Japan's diplomatic bluebooks. As it turns out, one needs to look beyond the official reasons for cooperation stated by the EU and Japan, and take into account the underlying economic incentives.

In the fifth chapter, Camille Van der Vorst covers one of the most vital achievements in the area of trade liberalisation as a result of the EU-Japan EPA: the removal of NTBs. For businesses, policymakers and economic analysts alike, it is important to get a grip on the extent of the liberalisation of these barriers, which is not easily measured. This chapter compiles the most burdensome NTBs mentioned by Japanese and European businesses and gives an overview of what is actually included in the EPA in terms of NTB liberalisation. This chapter also estimates whether the most burdensome barriers will be removed as a result of the EPA and whether there is still room for improvement. Although many of the barriers mentioned by businesses are covered in the EPA, the practical implementation of the Agreement will determine much of the real increase in market access that businesses will experience.

In the sixth chapter, Fukunari Kimura focuses on global economic governance through the establishment of mega FTAs. This chapter explores whether some of the earliest mega FTAs, such as the Comprehensive and Progressive Agreement for Trans-Pacific Partnership (CPTPP) might provide a blueprint 
for future economic governance through plurilateral PTAs. By analysing the trade liberalisation and standards that are achieved in the CPTPP, the chapter draws conclusions on the quality of market access that the Agreement might offer as inspiration for other future mega FTAs. It is found that plurilateral agreements with CPTPP-style standards are viable options for certain developing economies, while such agreements could also contribute to salvaging the WTO in times of trade turmoil.

In Chapter 7, Ines Willemyns and Jan Wouters take a legal view on EUJapan cooperation and the EU and Japan as long-term trading partners. Japan and the EU have sided together on several issues in international trade ever since they experienced a shift from being adversaries on trade to being allies starting in the 1990s. In light of the EU-Japan EPA, the authors tackle several of these issues on international trade and how cooperation between them took place. Additionally, this chapter finds issues of contention as well, such as the early GATT dispute settlement system. Most importantly, however, Japan and the EU were part of the 'Quad' negotiation group, which was vital during the process to establish the WTO.

In Chapter 8, Eiji Ogawa and Michiru Sakane discuss global financial governance by comparing past experiences of the EU and Japan with the handling of financial crises. There is a strong focus on the IMF's involvement in the Asian financial crisis of 1997-98 and its involvement in the European countries hit by the global financial crisis that erupted in 2007. This chapter finds stark differences in the way the IMF handled these two crises and the way in which the organisation cooperated with the countries that were affected. The authors recommend regional financial arrangements (RFAs) as a means to prevent and manage financial crises in the future and discuss how RFAs were involved in the Japanese and European experiences.

In Chapter 9, Michael Reiterer looks at the involvement of the EU and Japan in global security governance and how recent events have pushed the two regions closer as 'strategic partners'. As such, the chapter covers a wide area of cooperation between the EU and Japan, from the EU-Japan SPA to cybersecurity and even the Iran Nuclear Deal. The chapter underlines the importance of the EU-Japan EPA and SPA, as they come at a critical moment in time and provide the two actors with a solid platform for cooperating on issues that have long been on the agenda for global governance. This chapter also highlights the importance of looking beyond trade in a partnership that holds an important potential for dealing with global societal challenges.

Finally, in Chapter 10, Yumiko Nakanishi discusses the protection of fundamental and human rights in European governance and how this might impact human rights governance in Asia. The focus lies on multilevel protection in Europe and analyses the legal interplay between the German Federal Constitutional Court and the Court of Justice of the European Union. This 
interplay is clearly illustrated through several court cases that highlight the functioning of multilevel protection and where there might be any issues in this type of governance. The chapter finds that, while there is currently no similar multilevel protection of fundamental rights in Asia, the EU's sphere of influence on this topic might reach as far as Japan. This final chapter makes an important contribution to the ideas that are presented in this volume on the EU-Japan partnership, namely that the impact of the partnership is not limited to the bilateral agreements that are in place but that through those agreements more attention will be given to good practices in both Japan and the EU, which will provide a source of inspiration to tackle issues at the domestic, regional and/or global level.

\section{EU-JAPAN COOPERATION IN TIMES OF COVID-19}

At the time this book goes to press, Europe and Japan among many other nations slowly come out of several months of lockdown due to an unprecedented pandemic in the contemporary era - the Covid-19 crisis. None of the contributors to this volume could have imagined that the world as we knew it would be threatened in such a fundamental way. None of the European and Japanese social systems and subsystems remains unharmed. Questions loom as to how this will impact European and Japanese societies and economies, and their domestic, regional and international politics in the short as well as mid and long term. Should we rethink the porosity of borders to prevent contamination from spreading? Should we reconsider the easy and low-cost worldwide mobility? Or should we, on the contrary, tackle the issues that threaten the world by more solidarity, more openness and more communication - in short: more connectivity?

In this unprecedented context, Japan and the EU find themselves taking the same side in the debates on a variety of issues. Does this mean that Japan and the Union are truly 'strategic partners', as they like to refer to themselves? In any case, there is a certain amount of natural connectivity between the two actors. On many of the current issues in global governance, such as trade, climate, agriculture and data protection, Japan and the EU have similar positions. The changing international political stage, however, is making it increasingly important for actors such as the Union and Japan to articulate their strategic visions and objectives in global governance. To this end both actors have to clarify whether they continue their support for the existing global order, or whether they would be ready to renounce their commitments by, amongst others, following the example of the US. At the same time, it is important to remember that Japan and the EU depend on each other if they want to maintain their influence in global governance, that is, if they want to retain their prominent roles in shaping the way our world functions. 
In the words of Yuval Noah Harari, we face the choice between 'nationalist isolation and global solidarity' to tackle problems that do not stop at the border. Harari eloquently writes that 'Humanity needs to make a choice. Will we travel down the route of disunity, or will we adopt the path of global solidarity? If we choose disunity, this will not only prolong the crisis, but will probably result in even worse catastrophes in the future.' ${ }^{61}$ The present volume shares this concern and inquires, through the prism of EU-Japan cooperation, how solidarity and inter-regional partnerships can generate added value for the international community as a whole. This is what the contributors aim at by focusing on the EU-Japan partnership from multiple and multidisciplinary perspectives. With that, we hope that this volume makes a meaningful contribution to the literature and debate. ${ }^{62}$

${ }^{61}$ Harari, Yuval Noah, 'The world after coronavirus', Financial Times, 20 March 2020.

62 Although the literature on the EU-Japan partnership is overall rather sparse, recently a group of scholars have published a valuable edited volume on the state of the relationship: Berkofsky, A., C. W. Hughes, P. Midford and M. Söderberg (eds), The EU-Japan Partnership in the Shadow of China: The Crisis of Liberalism, Routledge, 2018. Another valuable contribution was made by Gilson, J., EU-Japan Relations and the Crisis of Multilateralism, Routledge, 2019. Earlier work by Gilson includes: Gilson, J., Japan and the European Union: A Partnership for the Twenty-First Century?, Macmillan, 2000. For further reading see also: Vanoverbeke, Dimitri, Takako Ueta, Frederik Ponjaert, Nicholas Peeters and Takao Suami (eds), Developing EU-Japan Relations in a Changing Regional Context: A Focus on Security, Law and Policies (Globalisation, Europe, and Multilateralism series), Taylor and Francis, 2017. 